\title{
MODEL PEMBELAJARAN BERBASIS PROJEK DALAM MEMPRODUKSI TEKS CERPEN DI SMA SMA N 8 CIREBON
}

\author{
Sobihah Rasyad, Jimat Susilo, dan Casmanto \\ FKIP Universitas Swadaya Gunung Jati Cirebon \\ jimatsusilo@fkip-unswagati.ac.id
}

Naskah diterima: 18 Agustus 2017; direvisi: 13 November 2017; disetujui: 20 November 2017

\begin{abstract}
Based on a preliminary study conducted in some high schools, most of the students experienced difficulties in writing their ideas in the form of short stories. This research, therefore, aimed at assisting students and teachers in producing short stories. The proposed solution is applying an instructional model based on projects. This research used quasi-experimental research method using non-equivalent control group design. This study took 60 students randomly as the sample from 385 students. The result shows that the mean of the experiment class was $91.43 \%$, which was categorized as very good. The projectbased instructional model was also effective based on a t-test calculation with its score of $7.45>2.04$.
\end{abstract}

Keyword: short story text, project based learning model, activity learning

\section{ABSTRAK}

Berdasarkan pengamatan awal yang dilakukan peneliti di beberapa sekolah khususnya SMA, sebagian besar siswa SMA sulit menuliskan gagasan dalam bentuk cerita pendek. Para guru belum mendapatkan cara yang tepat mendorong siswa menulis cerita pendek. Berdasarkan pertimbangan itu, penelitian ini bertujuan membantu siswa dan guru dalam pembelaran memproduksi teks cerita pendek. Solusi yang ditawarkan adalah penerapan model pembelajaran berbasis proyek. Metode penelitian yang digunakan untuk mencapai tujuan tersebut adalah metode eksperimen semu dengan nonequivalen control group design. Jumlah populasi dalam penelitian ini sebanyak 385 siswa dan sampel yang digunakan 60 siswa. Berdasarkan hasil penelitian aktivitas siswa pada kelas eksperimen juga mendapat nilai rata-rata $91,43 \%$ dengan kategori sangat baik dan pembelajaran berbasis proyek efektif berdasarkan perhitungan t-tes, diperoleh nilai 7,45 > 2,04.

Kata kunci: teks cerita pendek, model pembelajaran berbasis proyek, aktivitas

\section{PENDAHULUAN}

Pembelajaran memproduksi teks cerita pendek terdapat di dalam Kompetensi Dasar (KD) 4.2, yaitu memproduksi teks cerita pendek yang sesuai dengan karakteristik teks. Kompetensi Dasar tersebut diajarkan pada siswa kelas XI SMA atau sederajat yang menggunakan Kurikulum 2013. Teks cerita pendek merupakan tulisan yang berbentuk pendek, bersifat narasi dan fiksi yang mengandung sebagian fragmen kehidupan manusia, dan memiliki nilai atau kesan tersendiri bagi pembaca. Menurut Sumardjo (2004:10), teks cerita pendek harus berupa cerita atau narasi (bukan analisis argumentatif) yang fiktif (tidak benar-benar terjadi, tapi dapat 
terjadi kapan saja dan di mana saja) serta relatif pendek.

Sesuai dengan penjelasan di atas, telah dilakukan studi pendahuluan dengan menyebarkan angket kepada 30 siswa yang berasal dari 3 sekolah yang berbeda, 10 siswa dari masing-masing sekolah mengisi angket tersebut. Selain menyebar angket, juga telah dilakukan wawancara dengan 3 narasumber yang berasal dari 3 sekolah yang berbeda.

Berdasarkan hasil angket tersebut diperoleh data, (1) 23 responden $(76,66 \%)$ merasa kesulitan saat menuangkan ide atau gagasan ke dalam bentuk tulisan, (2) 18 responden $(60 \%)$ tidak mengetahui struktur teks cerita pendek, mereka hanya mengetahui unsur intrinsik cerita pendek, dan (3) 21 responden (70\%) berpendapat guru jarang memberikan penguatan atau motivasi supaya siswa terus berlatih menulis teks cerita pendek.

Berdasarkan permasalahan tersebut, perlu adanya solusi untuk mengatasi atau meminimalisasi kesulitan yang dihadapi siswa. Seperti menerapkan model pembelajaran lain yang dapat meningkatkan pemahaman, kemampuan, dan keterampilan siswa dalam memproduksi teks cerita pendek.

Menurut Daryanto (2014:23) model pembelajaran berbasis proyek merupakan metode belajar yang menggunakan masalah sebagai langkah awal dalam mengumpulkan dan mengintegrasikan pengetahuan baru berdasarkan pengalamannya dalam beraktivitas secara nyata. Berbeda dengan pendapat tersebut, Kosasih (2014:37) menjelaskan bahwa model pembelajaran berbasis proyek lebih memfokuskan pada aktivitas siswa berupa pengumpulan informasi dan pemanfaatannya untuk menghasilkan sesuatu yang bermanfaat bagi kehidupan siswa itu sendiri ataupun orang lain, tetapi tetap terkait dalam KD yang ada dalam kurikulum.

Model pembelajaran berbasis proyek merupakan model pembelajaran yang menekankan aktivitas siswa dalam proses pembelajaran. Menurut Sutirman (2013:43) model pembelajaran berbasis proyek adalah model pembelajaran yang melibatkan siswa secara aktif dalam merancang tujuan pembelajaran untuk menghasilkan produk atau proyek yang nyata. Keterlibatan siswa dalam proses pembelajaran dapat terjadi karena adanya produk atau proyek nyata yang harus dihasilkan sehingga siswa perlu merancang tujuan pembelajaran sesuai dengan minat dan pengetahuan mereka, baik secara individu maupun berkelompok.

Sejalan dengan pendapat di atas, Abidin (2014:167) menjelaskan bahawa model pembelajaran berbasis projek sebagai suatu model pembelajaran, secara langsung melibatkan siswa dalam proses pembelajaran melalui kegiatan penelitian untuk mengerjakan dan menyelesaikan projek pembelajaran tertentu. Kegiatan penelitian merupakan cara yang harus ditempuh siswa untuk memperoleh pengetahuan dan pengalaman baru yang disesuaikan dengan kebutuhan. Selanjutnya, hasil penelitian tersebut akan digunakan siswa untuk mengerjakan dan menyelesaikan proyek pembelajaran.

Setiap model pembelajaran memiliki langkah-langkah kegiatan. Hal ini, dimaksudkan untuk memperjelas bagaimana tahapan yang harus ditempuh dalam menggunakan suatu model pembelajaran. Menurut Daryanto (2014:27), langkah-langkah model pembelajaran berbasis proyek adalah (1) penentuan pertanyaan mendasar, (2) mendesain perencanaan proyek, (3) menyusun jadwal, (4) memonitor siswa dan kemajuan proyek, (5) menguji hasil, dan (6) mengevaluasi pengalaman.

Dalam usaha memproduksi teks cerita pendek, siswa diwajibkan membuat sebuah tulisan yang sesuai dengan materi ajar. Memproduksi dapat dikatakan sebagai aktivitas untuk menghasilkan suatu produk. Hubungannya dengan penjelasan di atas, bahwa produk yang akan dihasilkan adalah sebuah tulisan. Pengertian memproduksi dalam hal ini sama artinya dengan menulis 
karena keduanya menghasilkan sebuah tulisan.

Menulis merupakan sarana yang tepat untuk menuangkan pemikiran, gagasan, dan perasaan yang diekspresikan dalam bentuk tulisan. Seperti yang dinyatakan Kusmayadi (2007:3) bahwa menulis adalah kegiatan mengolah pikiran, mengasah perasaan, dan mengomunikasikan hasil pemikiran melalui tulisan. Sejalan dengan pendapat tersebut, Semi (2007:14) menyatakan bahwa menulis adalah proses kreatif memindahkan gagasan ke dalam lambang-lambang tulisan. Menulis dapat dikatakan sebagai proses kreatif karena adanya pengalihan gagasan dari pikiran ke dalam bentuk tulisan. Seperti menulis teks cerita pendek.

Cerita pendek atau yang sering diakronimkan menjadi cerpen merupakan cerita yang memiliki bentuk atau wujud pendek. Seperti yang dikemukakan Kosasih (2012:34) bahwa cerita pendek adalah cerita yang menurut wujud fisiknya berbentuk pendek. Kriteria ukuran panjang pendek teks cerita pendek memang relatif. Namun, pada umumnya teks cerita pendek adalah cerita yang habis dibaca sekitar sepuluh menit sampai dengan setengah jam. Teks cerita pendek sering diistilahkan dengan cerita yang dapat dibaca dalam satu kali duduk.

Melengkapi pendapat di atas, Esten (2013:7) menyatakan bahwa cerita pendek adalah pengungkapan suatu kesan yang hidup dari fragmen kehidupan manusia. Artinya, teks cerita pendek hanya menyajikan sebagian kehidupan manusia yang terjadi pada suatu kesatuan waktu. Sehingga tidak dituntut adanya perubahan jalan hidup atau nasib para tokohnya.

Adapun yang dimaksud dengan memproduksi teks cerita pendek adalah aktivitas menuangkan gagasan atau perasaan untuk menghasilkan sebuah tulisan atau teks yang memiliki bentuk pendek, bersifat narasi dan fiksi, serta di dalamnya terdapat fragmen kehidupan manusia yang memiliki nilai tersendiri bagi pembaca. Oleh karena itu, orang yang akan menulis teks cerita pendek harus mengetahui lebih dulu struktur, kaidah kebahasaan, dan unsur pembangunnya.

Setiap teks memiliki struktur. Dengan adanya struktur teks, sebuah teks mudah untuk dibangun. Demikian pula dengan teks cerita pendek. Menurut Kosasih (2014:133), struktur teks cerita pendek memiliki enam bagian utama, yaitu abstrak, orientasi, komplikasi, evaluasi, resolusi, dan koda. Menurut Kurniwan dan Sutardi (2012:78), langkah-langkah menulis teks cerita pendek adalah (1) pencarian ide, (2) pengendapan dan pengolahan ide, (3) penulisan, (4) penyuntingan dan revisi.

Pada penelitian sebelumnya model pembelajaran berbasis proyek telah digunakan oleh Hanung Setya Wibowo, Kartono, dan M. Ismail Sriyanto dalam meningkatkan kemampuan menulis deskripsi, Evi Susanti, Br. Ginting, dan Mutsyuhito Solin dalam meningkatkan kemampuan memproduksi teks cerita pendek, dan I Ketut Turyantana dalam meningkatkan kemampuan menulis karya ilmiah. Berdasarkan hasil penelitian dengan menggunakan model pembelajaran berbasis proyek nilai rata-rata kemampuan siswa dalam menulis meningkat.

Berdasarkan studi pendahuluan yang telah dilakukan, penelitian ini bertujuan untuk mendeskripsikan aktivitas siswa dalam pembelajaran memproduksi teks cerita pendek dan untuk mengetahui efektivitas penerapan model pembelajaran berbasis proyek dalam memproduksi teks cerita pendek .

\section{METODE PENELITIAN}

Metode penelitian yang digunakan pada penelitian ini adalah metode eksperimen semu dengan desain penelitian yang digunakan dalam penelitian ini adalah nonequivalen control group design. Menurut Sugiyono (2011:79), nonequivalent control group design hampir sama dengan pretest-posttest control group design. Dalam penelitian ini selain kelompok eksperimen terdapat juga 
kelompok pembanding atau kelompok kontrol. Namun, pada desain ini kelompok eksperimen dan kelompok kontrol tidak dipilih secara acak. Pemilihan kelompok eksperimen dan kelompok kontrol harus sesuai dengan populasi yang telah dipilih.

Populasi penelitian ini adalah seluruh siswa kelas XI SMA Negeri 8 Cirebon dengan jumlah 385 yang terbagi ke dalam 11 kelas. Sampel yang digunakan adalah teknik purposif. Sampel penelitian ini adalah siswa kelas XI IPA 4 sebagai kelas eksperimen berjumlah 30 siswa dan kelas XI IPA 3 sebagai kelas kontrol berjumlah 30 siswa.

Teknik yang digunakan untuk mengumpulan data dalam penelitian ini, yaitu tes dan observasi. Tes digunakan untuk mengetahui kemampuan siswa dalam pembelajaran memproduksi teks cerita pendek dengan menggunakan model pembelajaran berbasis projek, dan observasi digunakan untuk mengamati kegiatan belajar siswa dalam pembelajaran memproduksi teks cerita pendek dengan menggunakan model pembelajaran berbasis projek.

Analisis statistik digunakan untuk menganalisis hasil tes memproduksi teks cerita pendek kelas XI dengan menggunakan statistik uji-t. Analisis nonstatistik digunakan untuk mendeskripsikan hasil data proses kegiatan pembelajaran memproduksi teks cerita pendek dengan menggunakan model pembelajaran berbasis projek

\section{HASIL PENELITIAN}

\section{Aktivitas Siswa dalam Pembelajaran}

Pengamatan dilakukan sebanyak dua

kali. Pertama, pada saat pembelajaran awal untuk mengetahui kemampuan awal siswa sebelum diberikan treatmen. Aktivitas siswa terlihat tidak antusias karena siswa terbentur dengan tugas yang belum jelas. Kedua, pembelajaran dengan menggunakan model PBL. Pembelajaran memproduksi teks cerita pendek dengan menggunakan model PBL menunjukkan bahwa aktivitas siswa kelas eksperimen memperoleh rata-rata persentase sebesar 91,43\% dengan kategori sangat baik. Hal ini tampak pada saat dilakukan evaluasi. Secara keseluruhan, siswa telah mengikuti kegiatan pembelajaran dengan aktif dalam menyelesaikan projek pembelajaran.

Pada aspek respons pertanyaan esensial yang diberikan guru, aktivitas siswa sangat baik $(86,67 \%)$ karena telah menjawab pertanyaan terkait dengan pengertian dan unsur intrinsik teks cerita pendek. Beberapa siswa $(13,23 \%)$ tidak memberikan respons karena melakukan aktivitas yang lain seperti mengobrol, melamun, dan bergurau. Setelah siswa merespons pertanyaan esensial yang diberikan guru, selanjutnya aspek membaca contoh teks cerita pendek. Kegiatan itu bertujuan menggali berbagai konten yang terdapat dalam contoh teks. Pada aspek ini aktivitas siswa sangat baik karena mampu memberi pendapat tentang isi teks cerita pendek yang telah dibaca, seperti menyebutkan bahwa di dalam teks tersebut ada narasi, dialog, dan lain-lain. Siswa yang aktif sebanyak 30 orang dengan persentase sebesar $100 \%$.

Kegiatan selanjutnya adalah menentukan struktur dan kaidah bahasa pada contoh teks cerita pendek yang telah dibaca. Kegiatan ini bertujuan mempertajam kemampuan siswa dalam memahami struktur dan kaidah bahasa teks cerita pendek karena proyek pembelajaran yang harus dihasilkan siswa adalah memproduksi teks cerita pendek yang sesuai dengan struktur dan kaidah kebahasaan. Pada aspek ini siswa yang aktif sebanyak 28 orang dengan persentase sebesar $93,33 \%$, sedangkan 2 siswa tidak mengikuti kegiatan tersebut karena melakukan aktivitas lain. Kegiatan selanjutnya aspek pembentukan kelompok. Siswa yang aktif sebanyak 30 orang dengan persentase sebesar $100 \%$. Aktivitas siswa pada aspek ini sangat baik karena telah sesuai dengan instruksi yang diminta oleh guru.

Kegiatan selanjutnya adalah berdiskusi untuk mendesaian projek pembelajaran. Pada kegiatan ini siswa menentukan tema 
proyek pembelajaran yang akan dihasilkan. Aktivitas siswa pada aspek ini sangat baik karena setiap kelompok telah mengajukan satu tema yang disertai dengan alasan. Di antara alasan tersebut dipilih salah satu dijadikan sebagai tema dalam proyek pembelajaran memproduksi teks cerita pendek. Siswa yang aktif pada kegiatan ini sebanyak 26 orang dengan persentase sebesar $86,67 \%$, sedangkan 4 siswa tidak mengikuti aspek tersebut karena melakukan aktivitas lain.

Kegiatan berikutnya adalah membuat penjadwalan proyek. Pada kegiatan ini aktivitas siswa sangat baik karena siswa mampu mengambil keputusan dalam menentukan waktu pengumpulan proyek secara bermusyawarah. Siswa yang aktif pada kegiatan ini sebanyak 26 orang dengan persentase sebesar $86,67 \%$, sedangkan 4 siswa tidak mengikuti aspek tersebut karena melakukan aktivitas lain.

Kegiatan berikutnya adalah menyimak hal-hal yang perlu diperhatikan sebelum memproduksi teks cerita pendek. Pada kegiatan ini siswa menunjukkan minat rasa ingin tahunnya walaupun ada 4 siswa yang tidak mengikuti aspek tersebut karena melakukan aktivitas lain sehingga siswa yang aktif sebanyak 26 orang dengan persentase sebesar $86,67 \%$.

Kegiatan berikutnya adalah membuat kerangka karangan. Pada kegiatan ini siswa yang aktif sebanyak 86,67\%. Data ini menunjukkan bahwa aktivitas siswa sangat baik karena telah membuat kerangka karangan sesuai dengan tema yang telah ditentukan. Empat siswa langsung membuat teks cerita pendek.

$$
\text { Kegiatan berikutnya adalah }
$$

memproduksi teks cerita pendek secara individu. Pada aspek ini aktivitas siswa sangat baik karena seluruh siswa membuat teks cerita pendek, siswa yang aktif sebanyak 30 dengan persentase sebesar $100 \%$.

Kegiatan berikutnya adalah menyunting. Aktivitas siswa pada kegiatan ini sangat baik $(86,67 \%)$ karena siswa mau mengikuti instruksi guru.
Kegiatan berikutnya adalah presentasi hasil kerja menulis teks cerita pendek. Pada kegiatan ini aktivitas siswa sangat baik karena perwakilan tiap kelompok telah mempresentasikan hasil memproduksi teks cerita pendek. Bahkan dalam satu kelompok ada yang berebut untuk presentasi. Siswa yang aktif pada kegiatan ini sebanyak 30 orang dengan persentase sebesar $100 \%$.

Kegiatan berikutnya adalah memberi pendapat atau penilaian terhadap teks cerita pendek yang telah dipresentasikan atau dibaca. Pada kegiatan ini aktivitas siswa sangat baik. Siswa yang aktif pada kegiatan ini sebanyak 26 orang dengan persentase sebesar $86,67 \%$.

Kegiatan berikutnya adalah mendengarkan penjelasan guru tentang hasil presentasi dan hasil tulisan siswa. Pada kegiatan ini aktivitas siswa sangat baik karena siswa telah menyimak dengan aktif $(86,67 \%)$.

Kegiatan terakhir adalah siswa dan guru menyimpulkan hasil pembelajaran. Aktivitas siswa dalam kegiatan ini sangat baik karena siswa secara bersama-sama menyimpulkan hasil pembelajaran yang telah dilaksakan dari awal hingga akhir. Pada kegiatan ini siswa yang aktif sebanyak 28 orang dengan persentase sebesar $93,33 \%$.

\section{Efektivitas Model Pembelajaran}

Berikut adalah pemaparan peningkatan hasil belajar siswa dalam memproduksi teks cerita pendek. Dari aspek struktur teks cerita pendek, pada bagian abstrak terdapat dua deskriptor penilaian yaitu terdapat gambaran keseluruhan isi cerita atau tidak terdapat gambaran keseluruhan isi cerita. Pada tes awal terdapat 2 siswa dengan persentase $6,67 \%$ dari jumlah keseluruhan siswa kelas eksperimen yang memuat deskriptor tersebut. Jumlah itu meningkat pada tes akhir sebanyak 8 siswa dengan persentase $26,67 \%$ dari jumlah keseluruhan.

Pada bagian orientasi terdapat dua deskriptor penilaian yaitu terdapat 
pengenalan penokohan dan pengenalan latar cerita. Pada tes awal terdapat 26 siswa dengan persentase $86,67 \%$ dari jumlah keseluruhan siswa sudah memuat deskriptor tersebut. Pada tes akhir jumlah tersebut meningkat sebanyak 30 siswa dengan persentase $100 \%$ dari jumlah keseluruhan.

Pada bagian komplikasi terdapat tiga deksriptor penilaian yaitu munculnya konflik, konflik semakin meningkat, dan puncak konflik. Pada tes awal terdapat 2 siswa dengan persentase $6,67 \%$ dari jumlah siswa sudah memuat deskriptor tersebut pada teks yang mereka buat. Pada tes akhir jumlah tersebut meningkat sebanyak 19 siswa dengan persentase $63,33 \%$ dari jumlah keseluruhan siswa.

Pada bagian evaluasi terdapat dua deskriptor penilaian yaitu terdapat alasan atau komentar pengarang yang mengulas komplikasi dan atau tidak terdapat alasan atau komentar pengarang yang mengulas komplikasi. Pada tes awal terdapat 2 siswa dengan persentase $37,5 \%$ dari jumlah keseluruhan siswa sudah memuat deskriptor tersebut. Pada tes akhir jumlah itu meningkat sebanyak 18 siswa atau $60 \%$ dari jumlah keseluruhan.

Pada bagian resolusi terdapat dua deskriptor penilaian yaitu terdapat penyelesaian konflik dan atau tidak terdapat penyelesaian konflik. Pada tes awal terdapat 13 siswa dengan persentase 43,33\% dari jumlah keseluruhan siswa sudah memuat deskriptor tersebut, sedangkan pada tes akhir jumlah meningkat sebanyak 28 siswa atau 93,33\% dari jumlah keseluruhan.

Pada bagian koda terdapat dua deskriptor penilaian yaitu terdapat nilainilai kebaikan yang dapat dipetik pembaca dan atau tidak terdapat nilai-nilai kebaikan yang dapat dipetik pembaca. Pada tes awal terdapat 4 siswa dengan persentase $13,33 \%$ dari jumlah keseluruhan siswa sudah memuat deskriptor tersebut. Pada tes akhir jumlah meningkat sebanyak 16 dengan persentase $53,33 \%$ dari jumlah keseluruhan.
Dari aspek kaidah kebahasaan teks cerita pendek, pada bagian gaya bahasa, terdapat 4 siswa dengan persentase $13,33 \%$ dari jumlah keseluruhan siswa sudah menggunakan gaya bahasa yang tidak bertele-tele dan tepat sasaran pada kelas kontrol. Pada tes akhir jumlah tersebut meningkat menjadi 13 siswa dengan persentase $43,33 \%$ dari jumlah keseluruhan. Pada bagian konjungsi temporal, terdapat 18 siswa dengan persentase $60 \%$ dari jumlah keseluruhan siswa memuat konjungsi temporal, jumlah tersebut meningkat pada tes akhir menjadi 30 siswa atau $100 \%$ dari jumlah keseluruhan.

\section{PEMBAHASAN}

\section{Aktivitas Siswa}

Keaktifan yang ditunjukan siswa merupakan bagian dari minat selama mengikuti proses pembelajaran. Selain itu, keaktifan siswa juga menunjukkan bahwa mereka terlibat secara langsung dalam proses pembelajaran. Seperti yang diutarakan Sutirman (2013:43) bahwa model pembelajaran berbasis proyek dapat meningkatkan keaktifan siswa selama proses pembelajaran karena adanya proyek pembelajaran yang harus dikerjakan. Dengan demikian, model pembelajaran berbasis proyek dapat meningkatkan keaktifan siswa selama proses pembelajaran karena ada kegiatan proyek yang harus dikerjakan siswa untuk mengahasilkan sebuah proyek pembelajaran, dalam hal ini teks cerita pendek.

Dalam pembelajaran berbasis proyek keaktifan siswa menjadi butir penting yang perlu diperhatikan. Guru sebagai motivator dan fasilitator harus memberi peluang kepada siswa untuk mengonstruksi belajarnya secara otonom. Hal ini bertujuan untuk membangun kemampuan dan keterampilan siswa selama proses pembelajaran. Sehingga pembelajaran yang telah dilaksanakan memiliki kebermakanaan bagi kehidupan siswa. Seperti yang dikemukakan Wasis (Sutirman, 2013:43) bahwa model 
pembelajaran berbasis proyek memiliki potensi yang sangat besar untuk memberi pengalaman belajar yang lebih menarik dan bermakna bagi siswa.

Keaktifan siswa dalam pembelajaran berbasis proyek masih bersifat umum sehingga perlu memutar lensa untuk memperbesar tampilan kegiatan yang menjadi karakteristik model pembelajaran tersebut. Seperti yang dikemukakan Daryanto (2014:24) bahwa dalam karakteristik model pembelajaran berbasis proyek siswa harus membuat sebuah keputusan tentang sebuah kerangka kerja, adanya permasalahan yang harus dikerjakan, dan adanya proses pengamatan yang harus dilakukan untuk menjawab permasalahan yang ada. Pendapat tersebut dapat dipahami bahwa model pembelajaran berbasis proyek mampu membuat siswa aktif karena setiap kegiatan yang ditempuh untuk menghasilkan sebuah proyek pembelajaran melibatkan siswa secara langsung. Sejalan dengan pendapat tersebut, Abidin (2014:167) menjelaskan bahwa model pembelajaran berbasis proyek sebagai suatu model pembelajaran yang secara langsung melibatkan siswa dalam proses pembelajaran melalui kegiatan penelitian untuk mengerjakan dan menyelesaikan proyek pembelajaran tertentu.

Berdasarkan hal tersebut dapat disimpulkan bahwa aktivitas siswa dalam proses pembelajaran memproduksi teks cerita pendek dengan menggunakan model pembelajaran berbasis proyek sangat baik. Keaktifan siswa dapat dilihat pada data hasil observasi selama kegiatan pembelajaran berlangsung. Keaktifan siswa pada kelas eksperimen dengan menerapkan model pembelajaran berbasis proyek mencapai nilai rata-rata sebesar $91,43 \%$. Nilai tersebut termasuk pada kategori nilai sangat baik. Menurut Sugiyono (2013:257) kategori aktivitas siswa dengan rentang nilai $75 \%$ sampai dengan $100 \%$ termasuk ke dalam kategori sangat baik. Dengan demikian dapat disimpulkan bahwa penggunaan model pembelajaran berbasis proyek dalam pembelajaran memproduksi teks cerita pendek pada siswa kelas XI SMA Negeri 8 Cirebon tahun pelajaran 2016/2017 dapat membuat siswa aktif dalam kegiatan pembelajaran di kelas.

\section{Efektivitas Model Pembelajaran}

Model pembelajaran yang tepat adalah mempunyai kemampuan untuk mengingkatkan kemampuan tertentu yang harus dimiliki siswa. Penelitian ini terfokus pada kemampuan memproduksi teks cerita pendek. Secara keseluruhan pada penelitian ini terdapat peningkatan hasil pembelajaran memproduksi teks cerita pendek baik di kelas kontrol maupun di kelas eksperimen. Peningkatan nilai rata-rata yang terjadi pada kelas eksperimen lebih tinggi dari pada kelas kontrol. Hal ini disebabkan karena penggunaan model pembelajaran berbasis proyek dapat meningkatkan hasil belajar siswa pada kelas eksperimen. Selain itu, model pembelajaran berbasis proyek juga sangat memotivasi siswa sehingga dapat mendorong siswa dalam menyelesaikan masalah dan meningkatkan kemampuan siswa dalam memproduksi teks cerita pendek.

Hasil tes awal pada kelas eksperimen menunjukkan siswa yang belum mencapai Kriteria Ketuntasan Mininal (KKM) sebesar 75 terdapat 21 siswa dan pada tes akhir sebanyak 28 siswa di kelas eksperimen dapat mencapai KKM. Sedangkan pada kelas kontrol pemerolehan tes awal sebanyak 26 siswa belum mencapai KKM sebesar 75 dan pada tes akhir 19 siswa dapat mencapai KKM.

Berdasarkan uraian di atas dapat diketahui bahwa nilai hasil tes kelas eksperimen lebih baik dari pada hasil tes yang diperoleh kelas kontrol. Hal ini dapat dilihat dari nilai rata-rata tes akhir yang diperoleh kelas eksperimen sebesar 84 sedangkan nilai rata-rata tes akhir yang diperoleh kelas kontrol sebesar 78,5.

Dari pernyataan di atas dapat disimpulkan bahwa hasil penelitian penerapan model pembelajaran berbasis proyek dalam pembelajaran memproduksi teks cerita pendek efektif. Model ini dapat 
meningkatkan kemampuan yang didukung dengan keaktifan siswa yang tinggi juga.

\section{SIMPULAN}

Pembelajaran memproduksi melalui model PBL dapat menghidupkan suasana kelas dalam pembelajaran. Melalui prosedur yang harus dilalui dalam menyelesaikan projek, siswa lebih fokus dalam memproduksi teks cerpen. Siswa mampu merancang dalam penyelesaian projeknya secara bertahap, yaitu dimulai dengan menggali berbagai konten yang ada di dalam contoh teks cerita pendek, kemudian siswa memberi pendapat tentang contoh teks tersebut terkait dengan berbagai konten yang terdapat di dalamnya. Selain itu, pada saat membuat perencanaan, penjadwalan, dan kerangka teks cerita pendek siswa juga aktif mendiskusikan tema, dan waktu pengumpulan proyek sebelum akhirnya mengembangkan kerangka karangan teks cerita pendek menjadi tulisan utuh secara individu. Dengan demikian tingkat keaktifan siswa dalam pembelajaran memproduksi teks cerita pendek dengan menerapkan model pembelajaran berbasis proyek sangat baik.

\section{PERSANTUNAN}

Penulis mengucapkan terima kasih kepada Rektor Unswagati Cirebon yang telah berkenan memberikan biaya penelitian. Tidak lupa juga penulis sampaikan ucapan terima kasih kepada Kepala SMA N 8 Cirebon beserta Guru Bahasa Indonesia yang telah memfasilitasi dan memberikan ruang untuk melakukan penelitian. Di samping itu, juga disampaikan kepada pengelola Jurnal Bahastra yang telah berkenan mempublikasikan hasil penelitian ini. Semoga hasil penelitian ini dapat bermanfaat dalam peningkatan kemampuan siswa dalam menulis cerpen.

\section{DAFTAR PUSTAKA}

Abidin, Y. (2014). Desain Sistem Pembelajaran dalam Konteks Kurikulum 2013. Bandung: Refika Aditama.
Daryanto. (2014). Pendekatan Pembelajaran Saintifik Kurikulum 2013. Yogyakarta: Gava Media.

Esten, M. (2013). Kesusastraan Pengantar Teori dan Sejarah. Bandung: Angkasa.

Kosasih, E. (2012). Dasar-dasar Keterampilan Bersastra. Bandung: Yrama Widya.

Kosasih, E. (2014). Strategi Belajar dan Pembelajaran Implementasi Kurikulum 2013. Bandung: Yrama Widya.

Kusmayadi, I. (2007). Menulis dengan Hati Membangun Motivasi Menulis. Bandung: Pribumi Mekar.

Semi, M. A. (2007). Dasard-dasar Keterampilan Menulis. Bandung: Angkasa.

Sugiyono. (2011). Metode Kuantitatif dan Kualitatif dan $R \& D$. Bandung: Alfabeta.

Sugiyono. (2013). Metode Kuantitatif dan Kualitatif dan $R \& D$. Bandung: Alfabeta.

Sumardjo, J. (2004). Seluk beluk dan Petunjuk Menulis Cerita Pendek. Bandung: Pustaka Latifah.

Sutardi \& Heru K. (2012). Penulisan Sastra Kreatif. Yogyakarta: Graha Ilmu.

Sutirman. (2013). Media dan Model-Model Pembelajaran Inovatif. Yogyakarta: Graha Ilmu. 